\title{
B12 Vitamini Düzeyinin Multiple Miyelom Kliniğine Etkisi
}

\section{Effect of Vitamin B12 Level on Multiple Myeloma Clinic}

\author{
Atakan Tekinalp ${ }^{1}$, \\ Sinan Demircioğlu ${ }^{1}$, \\ Hakan Bilgen², \\ Hatice Zeynep Dikici ${ }^{1}$, \\ Özcan Çeneli ${ }^{1}$
}

${ }^{1}$ Necmettin Erbakan Üniversitesi, Meram Tıp Fakültesi, Iç Hastalıkları Anabilim Dalı, Hematoloji Bilim Dalı, Konya

${ }^{2}$ Necmettin Erbakan Üniversitesi, Meram

Tıp Fakültesi, İç Hastalıkları Anabilim Dalı, Konya

Geliş Tarihi/Received: 29 Mayıs 2020

Kabul Tarihi/Accepted: 5 Ağustos 2020

Yazışma Adresi: Atakan Tekinalp, Necmettin Erbakan Üniversitesi Meram Tıp Fakültesi, İç Hastalıkları Anabilim Dalı, Hematoloji Bilim Dalı, Konya

e-posta: atakantekinalp@hotmail.com

\section{ORCID}

Atakan Tekinalp

https://orcid.org/0000-0001-7937-4045

Sinan Demircioğlu

https://orcid.org/0000-0003-1277-5105

Hakan Bilgen

https://orcid.org/0000-0002-8359-0389

Hatice Zeynep Dikici

https://orcid.org/0000-0002-8489-8326

Özcan Çeneli

https://orcid.org/0000-0003-2541-1335
Öz

Amaç: Çalışmamız multipı miyelom (MM) hastalarında, tanıda bakılan serum B12 vitamini düzeyi ile klinik ve laboratuvar bulguların karşılaştırılmasını amaçlamaktadır.

Hastalar ve Yöntem: 2010-2020 yılları arasında MM tanısı alan hastalar değerlendirildi. Hastalar vitamin B12 düzeylerine göre düşük ve normal olmak üzere iki gruba ayrıldı. Veriler dağılım özelliklerine göre bağımsız örneklem T, Mann Whitney U ve ki-kare testleri ile karşılaştırıldı.

Bulgular: Retrospektif dosya incelemesi yapılan 212 hastadan çalıșmaya dahil edilen 128 hastanın 41 (\%32)'inde vitamin B12 eksikliği tespit edildi. Kemik iliği plazma oranı bu grupta anlamlı olarak daha düşük bulundu; medyan \%30'a karşın \%50 (p: 0,024). Iki grup arasında yaş, total protein, laktat dehidrogenaz, B2-mikroglobulin, kalsiyum, kreatinin, albumin ve litik lezyon varlığı açısından fark saptanmadı. Ancak vit B12 düzeyi düşük olan grupta 11 hastada $(\% 26,8)$, normal olan grupta ise 44 hastada $(\% 50,5)$ anemi tespit edildi. Normal olan grupta anemi sıklığının yüksekliği istatiksel olarak anlamlı bulundu $(p: 0,019)$. Ayrıca ISS ve R-ISS evreleri arasında da vitamin B12 düzeyleri açısından fark saptanmadı.

Sonuç: Düşük vitamin B12 düzeyinde kemik iliği plazma hücre oranı daha düşük bulunmaktadır. Verilerimiz ile bunun klinik yansıması gösterilememiştir. Tedavi yanıtı, sağ kalım ve relaps oranları gibi klinik verilerin değerlendirildiği çalışmalara intiyaç duyulmaktadır.

Anahtar Kelimeler: Miyelom, plazma-hücresi, Vitamin B12

\section{Abstract}

Aim: The aim of our study is evaluate the association between serum vitB12 levels at time of diagnosis and clinical and laboratory signs in multiple (MM) myeloma patients

Patients and Methods: Patienst diagnosed MM between 2010-2020 were evaluated. Patients were divided into two groups; those had low and normal levels of vitB12. Groups were analized by using independent simple T, Mann Whitney $\mathrm{U}$ and chi-square tests considering by distrubition characteristics of data.

Results: Two hundred-and-twelve patients' records were examined retrospectively. Forty-one (32\%) patients had low vitB12 levels. In patients with low vit B12 levels, bone marrow plasma cell ratios were also significantly lower than those found normal vit B12 levels (median $\% 30$ vs $\% 50$, respectively) ( $p$ : $0,024)$. There was no statistically significant difference between the two groups in terms of age, Iytic bone lesion numbers, and serum levels of total protein, lactate dehydrogenase, ß2-microglobulin, calcium, creatinin, albumin. However, 11 patients $(\% 26,8)$ in low vitB12 group had anemia, while $44(\% 50,5)$ patients in normal vitB12 group had. So, anemia was more often in vitamin B12 normal group patients ( $\mathrm{p}$ : $0,019)$. No difference was found in terms of myeloma ISS and R-ISS stages in two patient groups. Conclusions: Bone marrow median plasma cell ratio was also low in the group with low vit B12 levels. Our data could not show its clinical reflection. Further studies with larger groups are required to evaluate the response to treatment, survival and recurrence rate.

Key words: Myeloma, plasma-cell, vitamin B12
Atıf yapmak için: Tekinalp A, Demircioğlu S, Bilgen H, Dikici HZ, Çeneli Ö. B12 Vitamini Düzeyinin Multiple Miyelom Kliniğine Etkisi. Selcuk Med J 2021;37(1): 11-16

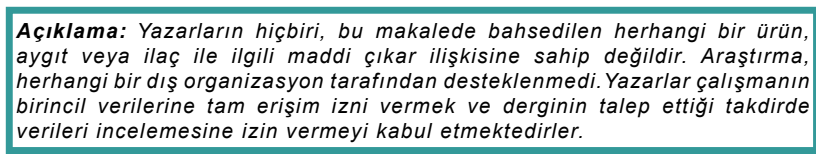

Açıklama: Yazarların hiçbiri, bu makalede bahsedilen herhangi bir ürün herhangi bir dış organizasyon tarafından desteklenmedi. Yazarlar çalışmanın verileri incelemesine izin vermeyi kabul etmektedirler. 


\section{GíRiş}

Multiple Miyelom (MM) plazma hücrelerinin monoklonal kontrolsüz proliferasyonu ile seyreden bir hematolojik neoplazidir. Tüm kanserlerin \%1'i ve hematolojik malignitelerin ise \%10'u MM'dur (1). Plazma hücrelerinin kemik iliği infiltrasyonuna bağlı başta anemi olmak üzere sitopeniler, plazma hücrelerinden salınan çeşitli sitokin ve büyüme faktörlerine bağlı litik kemik lezyonları ve fraktürler, hiperkalsemi ile renal yetmezlik hastalığın temel klinik özelliklerini oluşturur (2). Son yıllarda sitogenetik ve moleküler genetik tekniklerin gelişmesi sonrası risk değerlendirmesi ve evrelemede revizyona gidilmiş ve tedavi risk grubu temelinde şekillenmiştir (3). Konvansiyonel kemoterapiye proteazom inhibitörleri ve immünmodülatör ilaçların eklenmesi ve uygun hastalara otolog kök hücre naklinin yapılmasıyla olumsuz risk özelliği taşıyan hastalarda 8 yıllık sağ kalım \%50'lerdedir. Buna rağmen monoklonal antikorlar gibi hedefe yönelik moleküller tedaviye eklense de MM relapslarla seyreden bir hastalık olma özelliğini korumaktadır (4).

B12 vitamini (vit B12) hücre proliferasyonu sırasında, DNA replikasyonunda önemli bir kofaktördür. Çeşitli çalışmalarda yüksek serum vitB12 düzeylerinde özellikle sigara ve alkol ilişkili kanserler ile hematolojik malignitelerin prevalansında artış olduğu gösterilmiş ve kısa vadede malignite riskinin 6-15 kat fazla olduğu ifade edilmiştir $(5,6)$. VitB12 eksikliği yüksekliğine göre daha yaygındır. Genellikle makrositer anemi, pansitopeni, glossit, motor ve duyusal nöropatiler ile karşılaşılır (7). Monoklonal antikorların anti parietal hücre etkinlikleri nöropati ilişkili absorbsiyon bozuklukları MM'da vitB12 eksikliği nedenlerindendir. Retrospektif analizlerde $M M$ ve diğer plazma hücre hastalıklarında \%13,6-26,6 oranda vitB12 eksikliği raporlanmıştır (8-10).

Vit B12 eksikliği ve kemik mineralizasyonu ile ilgili çeşitli araştırmalar yapılmış, düşük vitB12, düşük osteokalsin düzeyi ile ilişkilendirilmiş ve dolayısıyla kemik metabolizmasının olumsuz etkilendiği belirtilmiştir (11). Osteoporoz ile vitB12 ilişkisi incelendiğinde vitB12 eksikliği olanlarda kemik mineral dansitesinde azalma olduğu saptanmış ve kadınlarda kalça kırığı sıklığında artış tespit edilmiştir $(12,13)$. Bu durumda MM hastalarında görülen vitB12 eksikliğinin, kemik hastalığını arttırabileceği akla gelebilir. Çalışmamızda MM tanılı olgularımızın serum vitB12 düzeylerine göre klinik ve laboratuvar bulguları karşılaştırılması amaçlandı.

\section{HASTALAR VE YÖNTEM}

Çalışmamızda Necmettin Erbakan Üniversitesi Meram Tıp Fakültesi, İç Hastalıkları Anabilim Dalı, Hematoloji Bilim Dalı'nda 2010-2020 yılları arasında MM tanısı alan ve takip edilen hastaların retrospektif dosya taraması yapıldı. Dosyası incelenen 212 hastadan Vit B12 replasmanı alan ve vit B12 değeri hastanemiz biyokimya laboratuvarı üst sınırı 990 pg/ ml'den yüksek olan hastalar çalışma dışında bırakıldı. Buna göre çalışmaya dahil edilen 128 hastanın tanı anında bakılan VitB12 düzeyleri, evre ve alt tipleri, risk grupları, hemoglobin $(\mathrm{Hb})$, kreatinin, kalsiyum, LDH, beta-2 mikroglobulin (ß2-MG), total protein ve albümin düzeyleri ile litik lezyon varlığı ve kemik iliği plazma hücre oranları kaydedildi. Çalışmamız için Necmettin Erbakan Üniversitesi Meram Tıp Fakültesi İlaç ve Tıbbi Cihaz Dışı Araştırmalar Etik Kurulu'ndan 2020/2453 numarası ile onay alındı.

\section{İstatistiksel Analiz:}

İstatistiksel analizler IBM SPSS Statistics 22 programı ile yapıldı. Sayısal veriler için bağımsız

Table 1. İki Grubun Cinsiyet, ISS ve MM Alt Tipine Göre Dağılımları

\begin{tabular}{|c|c|c|c|}
\hline & $\begin{array}{l}\text { Vit B12 }<220 \\
n(\%): 41(32)\end{array}$ & $\begin{array}{l}\text { Vit B12 } \geq 220 \\
\text { n }(\%): 87(68)\end{array}$ & $\begin{array}{l}\text { Toplam } \\
\text { n (\%): } 128(100)\end{array}$ \\
\hline \multicolumn{4}{|l|}{ Cinsiyet } \\
\hline Kadın & $14(34,1)$ & $35(40,2)$ & $49(38,3)$ \\
\hline Erkek & $27(65,9)$ & $52(59,8)$ & $79(61,7)$ \\
\hline \multicolumn{4}{|l|}{ ISS } \\
\hline Evre-I & $6(14,6)$ & $21(24,1)$ & $27(21,1)$ \\
\hline Evre-II & $18(43,9)$ & $26(29,9)$ & $44(34,4)$ \\
\hline Evre-III & $17(41,5)$ & $40(46,0)$ & $57(44,5)$ \\
\hline \multicolumn{4}{|l|}{ MM-Alt Tip } \\
\hline IGG & $23(56,1)$ & $55(63,2)$ & $88(60,9)$ \\
\hline IGA & $9(22)$ & $18(20,7)$ & $27(21,1)$ \\
\hline Serbest Kappa & $6(14,6)$ & $7(8)$ & $13(10,2)$ \\
\hline Serbest-Lambda & $3(7,3)$ & $7(8)$ & $10(7,8)$ \\
\hline
\end{tabular}


örneklem T, Mann Whitney $U$ ve Kruskal Wallis testleri; kategorik veriler için ki-kare testi kullanıldı. Sonuçlar \%95 güven aralığında $(p<0,05)$ anlamlılıkla değerlendirildi.

\section{BULGULAR}

Serum vit B12 alt sınırı, hastanemiz biyokimya laboratuvarında belirtilen 220 pg/ml kabul edildi. Buna göre hastaların 41 (\%32)'inde vit B12 eksikliği tespit edildi. Vit B12 düzeyi düşük ve normal olan iki grupta sırasıyla medyan vit B12 düzeyi; 180 pg/ml (114-217) ve $347 \mathrm{pg} / \mathrm{mL}$ (221-980) ve yaş ortalaması $64,5 \pm 11,4$ ve $64,6 \pm 10,1$ bulundu. Vit-B12 vitamin düzeyi düşük ve normal olan olguların cinsiyet, evre (ISS) ve MM alt tipi dağılımları tablo-1'de verilmiştir.

İki grup arasında evreleme parametreleri olan serum albümin ve ß2-MG düzeyleri açısından anlamlı fark bulunmazken, kemik iliği plazma hücre oranı vit B12 eksikliği olan grupta istatistiksel anlamlı olarak düşük bulundu (medyan plazma hücresi \%30'a karşın \%50, p: 0,024). Tablo-2'de de görüldüğü gibi yaş, total protein, LDH, ß2-MG, Ca, kreatinin, albumin ve litik lezyon varlığı açısından iki grup arasında anlamlı bir fark saptanmadı. Ancak vit B12 düzeyi düşük olan hastaların $\mathrm{Hb}$ ortalaması anlamlı olarak yüksek bulundu $(p<0,001)$. Ayrıca vit B12 düzeyi düşük olan 41 hastanın 11'inde $(\% 26,8)$, normal olan 87 hastanın 44'ünde $(\% 50,5)$ anemi mevcuttu ve istatistiki olarak anlamlı idi ( $p$ : 0,019). İki grubun medyan ferritin değerleri sırasıyla $101,1 \mu \mathrm{g} / \mathrm{L}$ ve 181 $\mu \mathrm{g} / \mathrm{L}$ olup fark anlamlı bulundu $(p=0,021)$. Medyan ferritin değeri anemisi olan hastalarda olmayanlara göre olarak şekilde yüksek bulundu $(228 \mu \mathrm{g} / \mathrm{L}$ ve 108 $\mu \mathrm{g} / \mathrm{L}, \mathrm{p}<0,001)$. Vit B12 değeri düşük olan hastalar anemi olup olmamasına göre iki gruba ayrılarak incelendiğinde; anemisi olan grubun ( $\mathrm{n}: 11)$ medyan MCV değeri olmayan (n:30) gruba göre yüksek olmakla beraber fark anlamlı değildi (96,6 fl ve 90,0 fl, p: 0,07). Anemik hastaların sadece 3'ünde MCV (fL) 100'ün üzerinde idi. İki grup ferritin, folik asit ve plazma hücre oranları açısından karşılaştırıldığında da anlamlı fark elde edilmedi (Sırasıyla $p=0,06$, $p=0,93, p=0,07$ ).

Kemik iliği plazma hücre oranı $\% 60$ eşik değer kabul edilerek iki grup oluşturulduğunda; plazma hücre oranı $\% 60$ ve üzerinde olan 46 hastanın 8'inde $(\% 17,4), \% 60$ 'ın altında olan 82 hastanın 33'ünde $(\% 40,2)$ ' sinde vitB12 düşük bulunmuş ve istatiksel anlamlı olarak değerlendirilmiştir (Ki-kare: 7,069, sd:1, p: 0,008). Plazma hücre oranı $\% 60$ ve üzerinde olan grupta medyan ferritin değeri daha düşük; medyan folik asit değeri ise daha yüksek bulunmuş ancak iki grup arasında anlamlı bir fark elde edilememiştir (ferritin; $151 \mu \mathrm{g} / \mathrm{L}$ ve $173 \mu \mathrm{g} / \mathrm{L}, \mathrm{p}=0,33$; folik asit; 7,2 $\mu \mathrm{g} / \mathrm{L}$ ve $6,8 \mu \mathrm{g} / \mathrm{L}, \mathrm{p}=0,55)$. Hastalar ISS evrelerine göre değerlendirildiğinde evre I, II ve III gruplarında vitB12 medyan değeri istatistiksel olarak anlamlı olmayıp sırasıyla; 276 pg/ml, 289 pg/ml ve 301 pg/ml bulunmuştur $(p=0,720)$. Ancak evre I ve II hastalarda medyan plazma hücre oranı $\% 30$, evre III hastalarda $\% 50$ olup fark, anlamlı kabul edilmiştir ( $p=0,017)$. Üç evrenin ikili karşılaştırmalarında evre I ve III için $p=0,008$; evre 2 ve 3 için $p=0,037$ hesaplanarak farklılık istatistiksel olarak gösterilmiştir.

Çalışmamızda değerlendirilen 128 hastadan 86 'sının sitogenetik incelemesine ulaşıldı. Karyotipik incelemesi ve panel olarak bakılan sitogenetik testleri normal olan 59 hastanın medyan VitB12 değeri 290 pg/ $\mathrm{mL}$, herhangi bir anomali taşıyan hastalarda ise 282 $\mathrm{pg} / \mathrm{ml}$ olup anlamlı bir fark tespit edilmedi ( $\mathrm{p}: 0,904)$. Genetik özelliği bilinmeyen olgular dışlandıktan sonra R-ISS evrelemesi yapıldı. Seksen altı hastanın evre-I, II ve III dağılımı sırasıyla 16 (\%18,6), 50 (\%58,1), 27 (\%31,3) bulundu. VtB12 eksikliği açısından üç grup arasında fark saptanmadı (Ki-kare:1,0, sd:2, p: 0,596).

\section{TARTIŞMA}

MM, sıklıkla ileri yaşta görülür, hastaların yaklaşık \%2'si 40 yaşın altıdadır ve medyan yaş 66'dır (14). Çalışmamızda VitB12 düzeyi < $220 \mathrm{pg} / \mathrm{ml}$ ve Vit $\mathrm{B} 12 \geq 220 \mathrm{pg} / \mathrm{mL}$ olan iki grubun medyan yaşları sırasıyla $66(36-85)$ ve 67 (40-89) olup literatürle uyumludur. Anemi ve ilişkili semptomları ile kemik ağrısı hastalığın en belirgin semptomları olup litik kemik lezyonları, çökme fraktürleri, serum kreatinin yüksekliği, hiperkalsemi, monoklonal protein yüküne bağlı hipervisikosite semptomları, nöropati ve enfeksiyona yatkınlık hastaların temel klinik özelliklerini oluşturur $(2,14,15)$. Anemi, MM'un en sık bulgusudur ve olguların \%73'ünde bildirilmiştir $(3,14)$. Değerlendirmemizde tüm hastaların 55'inde $(\% 42,9)$ tanıda anemi mevcuttu. VitB12 düzeyine göre incelediğimizde; VitB12 düzeyi düşük olan 41 hastadan 11 'inde $(\% 26,8)$, normal olan 87 hastanın ise 44 'ünde $(\% 50,5)$ anemi tespit edildi. VitB12 düzeyi normal olan hasta grubunda anemi sıklığının yüksek olması İstatistiksel olarak anlamlı bulundu $(X 2=5,480$, $s d=1$ $p=0,019)$. Bu durum MM'da plazma hücre infiltrasyonu ve sitokin salınımına bağlı eritropoezin baskılanması gibi başka faktörlerin de anemi patogenezinde etken olduğunu düşündürmektedir (16). Ayrıca anemisi olan 
hastalarda ferritin değeri daha yüksek bulunması bu savı desteklemektedir. Bu hastaların çoğunun renal yetmezlik tablosu ve eritrosit replasmanları sonrası başvurduğu tespit edilmiştir. MM hastalarında vitB12 düzeyinde değişiklikler olduğu gösterilmiş, farklı çalışmalarda \%11-30,6 oranlarında vitB12 eksikliği bildirilmiştir (14,17-19). Çalışmamızda bu oran \%32 olup verilerden bir miktar yüksektir. Replasman altında olan hastaların değerlendirme dışı tutulması bu yüksekliği açıklayabilir.

Pernisiyöz anemi, vitB12 eksikliğinin en sık nedenidir (20). Paraproteinlerin anti-intrensek faktör etkinliğine bağlı pernisiyöz anemi gelişeceği üzerinde durulmuştur. Bazı çalışmalarda $\lg A$ tipi önemi bilinmeyen monoklonal gammopati ve MM'da pernisiyöz anemi ve dolayısıyla vitB12 eksikliğinin daha sık görüldüğü gözlenmiştir $(10,17)$. Çalışmamızda IgA alt tipindeki 9 (\%22) hastanın vitB12 düzeyi düşüktü ve alt tipler arasında vitB12 düzeyleri açısından anlamlı bir fark saptanmadı $(p=0,105)$. MM ile VitB12 ilişkisini açıklamaya yönelik çalışmaların hücre içi VitB12 düzeyi ve serumda vitB12 taşıyıcılarının ölçümleriyle yapılmıştır. Ermens ve ark.nın çalışmasında $12 \mathrm{MM}$ hastasından kemik iliği aspiratı ile elde edilen plazma hücrelerinde kobalamin düzeyi ölçülmüş ve 7 hastada intrasellüler kobalamin düzeyi 200 pg/ml'den düşük bulunmuştur (21). Arnalich ve ark. da "high-grade" şeklinde ifade ettikleri 26 hastada, apotranskobalamin-II (apo TCII) seviyesini "low-grade" MM hastalarına göre daha yüksek ölçülmüştür. İki hasta grubu arasında VitB12 düzeyleri arasında anlamlı bir fark saptanmamıştır (22). VitB12'nin yaklaşık \%10-30'u hücre içine TCII ile taşınır. VitB12'nin hücre içine taşınmasını reseptör düzeyinde inceleyen çalışmalarda, araştırıcılar reseptör yapısındaki değişikliklerin serum vitB12 düzeyini etkilediğini ifade etmiştir $(21,23)$. Diğer yandan myeloproliferatif hastalıklarda, artmış myeloid hücrelerden salınan haptokorrine bağlı olarak VitB12 düzeyinin yüksek saptandığı gösterilmiştir (22-24). Proliferasyonla seyreden bu hastalıklarda vitB12 seviyelerindeki farklılıklar tüketim ile açıklanmaya çalışılmıştır. MM, plazma hücrelerinin klonal proliferasyonu ile karakterize bir hastalıktır (1). Literatürde kemik iliği plazma hücre oranı ile vitB12 düzeyi arasında ilişkiyi gösteren bir veri mevcut değildir. Çalışmamızda vitB12 düzeyi düşük olan grupta kemik iliği plazma hücre oranı, vitB12 düzeyi normal olan gruba göre anlamlı olarak daha düşük bulunmuştur (Medyan \%30'a \%50). MM'un güncel tanı kriterlerinde MM'u tanımlayıcı olaylar incelendiğinde, klinik bulgular olmadan da kemik iliği plazma hücre oranı \%60'ın üzerinde ise MM tanısı konulmaktadır (3). Bu çerçevede hastalarımızı kemik iliği plazma hücre oranı $\% 60$ eşiği temellinde kategorize ettiğimizde; kemik iliği plazma hücre oranı \%60'ın altında olan hastalarda vitB12 düşüklüğünün anlamlı olarak daha sık olduğu görülmüştür (\%17,4'e $\% 40,2)$. Her iki bulgu vitB12 düzeyi ile kemik iliği plazma hücre oranının ilişkili olabileceği fikrini vermektedir. Diğer yandan medyan ferritin değerinin VitB12 düzeyi < $220 \mathrm{pg} / \mathrm{ml}$ grupta daha düşük olması, demirin de hücre gelişimindeki önemini desteklemektedir (25). Bu bulgular, vitB12 düzeyi düşük olan grupta plazma hücre oranın daha düşük bulunmasına, başka faktörlerin de etkili olabileceğini akla getirmektedir. DNA sentezi ve dolayısıyla hücre proliferasyonunda etkisi olduğu bilinen VitB12 düşük olduğu için mi plazma hücre oranı daha düşük bulunmuştur sorusuna hücresel çalışmalar yaparak cevap vermek daha doğru olacaktır. Çünkü plazma hücrelerinin kemik iliği $\mathrm{T}$ lenfositleri, makrofaj ve osteoblastlar gibi kemik iliği nişi ile etkileşimi, IL-6 gibi sitokinler, klonal plazma hücresinde gelişen genetik anomaliler ve mikro RNA düzeyinde tespit edilen epigenetik değişiklikler gibi pek çok faktör plazma hücre proliferasyonunu etkilemektedir (26-30).

Çalışmamızda vitB12 düzeyi düşük olan hastalarda plazma hücre oranı her ne kadar anlamlı şekilde düşük bulunsa da bunun klinik yansıması izlenmemektedir. Çeşitli yayınlarda vitB12 düzeyleri ile kemik hastalığı ile ilgili verilere ulaşılmıştır. Yıkılmaz et al. (18) vitB12 düzeyi 200 pg/ml'nin altındaki MM hastalarında kemik fraktürü ve hiperkalsemini sıklığını sırasıyla \%44,8 ve $\% 37,9$ oranlarında bulmuştur. Çalışmamızda ise kemik fraktür sıklığı değerlendirilmemiş ancak vitB12 seviyesi düşük ve yüksek olan hastaların, litik lezyon sıklığı ve serum kalsiyum düzeyleri arasında anlamlı bir fark elde edilememiştir (Tablo-2). Ayrıca iki grup arasında hastalık yükünü gösteren serum albümin, ß2-MG ve LDH düzeyleri arasında da anlamlı bir fark bulunmamıştır. Arnalich et al. (22) TC-II ve ß2-MG arasında pozitif bir korelasyon olduğunu bildirmiştir. Çalışmamızda TC-II düzeylerinin bilinmemesi nedeniyle vitB12 ile ß2-MG ilişkisinin yorumu sınırlı kalmıştır. Bilindiği gibi ß2-MG düzeyi $5,5 \mathrm{mg} / \mathrm{L}$ 'nin üzeri hastaları ISS'ye göre Evre IIl'e taşımaktadır (3). Hastalar vitB12 grupları evre dağılımlarına göre incelendiğinde; hem ISS evreleri hem de sitogenetik özellik taşıyıp taşımadığı bilinen hastaların dahil edildiği R-ISS evreleri arasında fark saptanmamıştır. $\mathrm{Bu}$ da vitB12 düzeyi ile klinik korelasyonun net 
Table 2. Iki Grubun Laboratuvar ve Klinik Bulguları *

\begin{tabular}{|c|c|c|c|}
\hline & $\begin{array}{l}\text { Vit } B 12<220 \\
(n: 41)\end{array}$ & $\begin{array}{l}\text { Vit } B 12 \geq 220 \\
\text { (n: 87) }\end{array}$ & $\mathbf{P}$ \\
\hline Yaş & $67(36-85)$ & $66(40-89)$ & $0,726^{a}$ \\
\hline Total Protein (mg/dL) & $8,3(4,2-12,9)$ & $8,6(5,5-16,6)$ & $0,109^{a}$ \\
\hline LDH (IU) & $210(80-510)$ & $198(86-679)$ & $0,793^{a}$ \\
\hline Beta-2 mikroglobulin (mg/dL) & $4,3(0,1-23,6)$ & $4,6(0,1-30)$ & $0,746^{a}$ \\
\hline Kalsiyum (mg/dL) & $9,0(7,2-12,3)$ & $9,3(7,0-15,6)$ & $0,098^{a}$ \\
\hline Kreatinin (mg/dL) & $1,0(0,5-2,5)$ & $1,0(0,5-7,4)$ & $0,364^{a}$ \\
\hline Ferritin $(\mu \mathrm{g} / \mathrm{L})$ & $101,1(13-1128)$ & $181(14-1778)$ & $0,021^{\mathrm{a}}$ \\
\hline Folik Asit $(\mu \mathrm{g} / \mathrm{L})$ & $6,8(3,2-12,8)$ & $7,5(2-24)$ & $0,295^{a}$ \\
\hline Plazma Hücre Oranı (\%) & $30(10-90)$ & $50(10-95)$ & $0,024^{a}$ \\
\hline $\mathrm{Hb}(\mathrm{g} / \mathrm{dL})$ & $11,5 \pm 2,2$ & $10,0 \pm 1,8$ & $0,000^{b}$ \\
\hline $\operatorname{MCV}(f L)$ & $91,1 \pm 7,4$ & $89,9 \pm 7,2$ & $0,337^{b}$ \\
\hline Albumin (mg/dL) & $3,4 \pm 0,7$ & $3,4 \pm 0,7$ & $0,804^{b}$ \\
\hline Litik Lezyonlu Hasta (n) & 33 & 64 & $0,527^{c}$ \\
\hline Anemisi Olan Hasta (n) & 11 & 44 & $0,019^{c}$ \\
\hline
\end{tabular}

olarak kurulamadığı savını desteklemektedir (ISS evrelemesine göre $p=0,720$, R-ISS evrelemesine göre $p=0,956$ ).

Çalışmamız kemik iliği plazma hücre oranı ve vitB12 eksikliği ilişkisini istatistiksel olarak göstermiştir. Ancak tedavi yanıtı, sağ kalım ve relaps oranları gibi prospektif klinik verilerin olmaması çalışmamızın temel sınırlandırıcı noktalarıdır.

Sonuç olarak düşük vitamin B12 düzeyinde kemik iliği plazma hücre oranı daha düşük bulunmaktadır. Elde ettiğimiz bu veri doğrultusunda monoklonal protein ve vitB12 metabolit düzeylerinin ölçümleri ile kemik iliği örnek alımı ve hematopatolojik değerlendirmenin standardize edileceği çalışmaların yapılması gerektiği kanısındayız.

Çıkar Çatışması: Çalışmada herhangi bir çıkar çatışması yoktur.

Finansal Çıkar Çatışması: Çalışmada herhangi bir finansal çıkar çatışması yoktur.

Yazışma Adresi: Atakan Tekinalp, Yunus Emre Mahallesi, Beyşehir Caddesi, Necmettin Erbakan Üniversitesi Meram Tıp Fakültesi Hastanesi, T Blok, 5. Kat. Meram, Konya, Türkiye 42090

Telefon: 0 (541) 6811611

e-mail: atakantekinalp@hotmail.com

\section{KAYNAKLAR}

1. Kyle RA, Therneau TM, Rajkumar SV, et al. Incidence of multiple myeloma in Olmsted County, Minnesota: Trend over 6 decades. Cancer 2004;101(11):2667-74.
2. Kyle RA, Rajkumar SV. Criteria for diagnosis, staging, risk stratification and response assessment of multiple myeloma. Leukemia 2009;23(1):3-9.

3. Rajkumar SV. Multiple myeloma: 2020 update on diagnosis, risk stratification and management. Am $\mathrm{J}$ Hematol 2020;95:548-67.

4. Goldschmidt H, Lokhorst HM, Mai EK, et al. Bortezomib before and after high-dose therapy in myeloma: Long-term results from the phase III HOVON-65/GMMG-HD4 trial. Leukemia 2018;32:383-90.

5. Arendt JF, Pedersen L, Nexo E, et al. Elevated plasma vitamin B12 levels as a marker for cancer: A population-based cohort study. J Natl Cancer Inst 2013;105:1799-805.

6. Arendt JF, Nexo E. Cobalamin related parameters and disease patterns in patients with increased serum cobalamin levels. PLoS One 2012;7:e45979.

7. Carmel R. How I treat cobalamin (vitamin B12) deficiency? Blood 2008;112(6):2214-21.

8. McShane CM, Murray LJ, Landgren $\mathrm{O}$, et al. Prior autoimmune disease and risk of monoclonal gammopathy of undetermined signicance and multiple myeloma: A systematic review. Cancer Epidemiol Biomark Prev 2014;23(2):332-42.

9. Braschi C, Doucette J, Chari A. Characterization of B12 deficiency in patients with plasma cell disorders. Blood 2015;126(23):5330.

10. Shimanovsky A, Argote JA, Murali S, et al. Autoimmune manifestations in patients with multiple myeloma and monoclonal gammopathy of undetermined signicance. BBA Clinical 2016;6:12-8.

11. Carmel R, Lau KH, Baylink DJ, et al. Cobalamin and osteoblast-specific proteins. N Engl J Med 1988;319(2):70-5.

12. Tucker KL, Hannan MT, Qiao N, et al. Low plasma vitamin B12 is associated with lower BMD: The Framingham Osteoporosis Study. J Bone Miner Res 2005;20(1):152.

13. Stone KL, Bauer DC, Sellmeyer D, et al. Low serum vitamin B-12 levels are associated with increased hip bone loss in 
older women: A prospective study. J Clin Endocrinol Metab 2004;89(3):1217.

14. Kyle RA, Gertz MA, Witzig TE, et al. Review of 1027 patients with newly diagnosed multiple myeloma. Mayo Clin Proc 2003;78(1):21.

15. Angelova EA, Li S, Wang W, et al. IgM plasma cell myeloma in the era of novel therapy: A clinicopathological study of 17 cases. Hum Pathol 2019;84:321.

16. Musto P, Falcone A, D'Arena G, et al. Clinical results of recombinant erythropoietin in transfusion-dependent patients with refractory multiple myeloma: Role of cytokines and monitoring of erythropoiesis. Eur J Haematol 1997;58(5):3149.

17. Baz R, Alemany C, Green R, et al. Prevalence of vitamin B12 deficiency in patients with plasma cell dyscrasias: $A$ retrospective review. Cancer 2004;101(4):790.

18. Ali Z, Faroqı $R$, Khan MF, et al. Incidence of decline in vitamin B12 level into diagnosed patients of multiple myeloma. PJMHS 2017;11(4):1249-52.

19. Şentürk Yıkılmaz A, Akıncı S, Silay K, et al. Vitamin B12 level have prognostic signi cance in multiple myeloma patients. Clin Oncol 2018;3:1434.

20. Carmel R. Prevalence of undiagnosed pernicious anemia in the elderly. Arch Intern Med 1996;156(10):1097.

21. Ermens AAM, Sonneveld P, Michiels JJ, et al. Increased uptake and accumulation of cobalamin by multiple myeloma bone marrow cells as a possible cause of low serum cobalamin. Eur J Haematol 1993;50(1):57-9.

22. Arnalich F, Zamorano AF, Martinez-Hernández $P$, et al. Additional predictive value of serum unsaturated vitamin B12 proteins in multiple myeloma. J Med 1990;21(5):277-86.
23. Quadros EV, Nakayama Y, Sequeria JM. The binding properties of the human receptor for the cellular uptake of vitamin B12. Biochem Biophys Res Comm 2005;327:100610.

24. Gimsing P, Overballe-Petersen CO, Hippe E. Cobalamin and cobalamin- binding proteins in plasma related to the clinical condition in chronic myelogenous leukemia. Leukemia 1995;9:1604-9.

25. Cairo G, Bernuzzi F, Recalcati S. A precious metal: Iron, an essential nutrient for all cells. Genes Nutr 2006;1(1):25- 36.

26. Dong C. TH17 cells in development: An updated view of their molecular identity and genetic programming. Nat Rev Immunol 2008;8(5):337-48.

27. Mantovani A, Germano G, Marchesi F, et al. Cancerpromoting tumor- associated macrophages: New vistas and open questions. Eur J Immunol 2011;41(9):2522-5.

28. Giuliani N, Rizzoli V. Myeloma cells and bone marrow osteoblast interactions: Role in the development of osteolytic lesions in multiple myeloma. Leuk Lymphoma 2007;48(12):2323-9.

29. Chesi M, Bergsagel Lefi P. Moleculer pathogenesis of multiple myelom: Basic and clinical uptades. Int J Hematol 2013;97(3):313-23.

30. Pichiorri F, Suh SS, Ladetto $M$, et al. MicroRNAs regulate critical genes associated with multiple myeloma pathogenesis. Proc Natl Acad Sci USA 2008;105(35):1288590. 